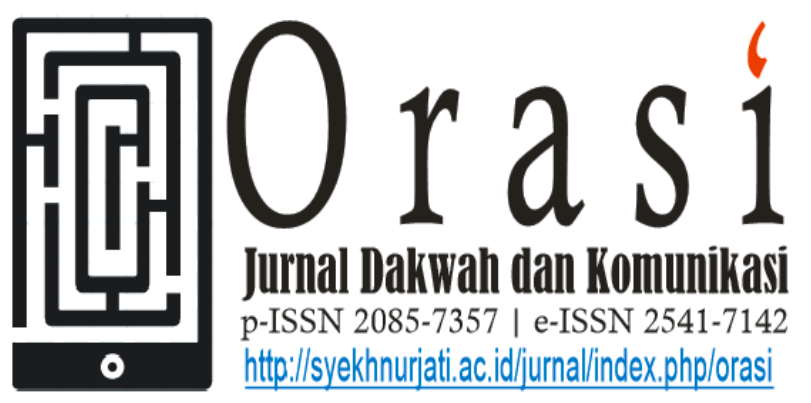

Volume 9 No. 2, PP 97 - 114; November 2018

\title{
PERBEDAAN GENDER DALAM PENGGUNAAN TELEPON SELULER
}

\author{
Yayah Nurhidayah \\ Dosen Jurusan Komunikasi dan Penyiaran Islam \\ Fakultas Ushuluddin Adab dan Dakwah IAIN Syekh Nurjati Cirebon \\ yayah.nurhidayah@syekhnurjati.ac.id
}

\begin{abstract}
ABSTRAK
Perkembangan teknologi komunikasi dan informasi telah membawa perubahan dalam berbagai aspek kehidupan Manusia. Teknologi kini menjadi kebutuhan kedua bagi manusia terutama di kota-kota besar. Perkembangan teknologi digital telah memicu perkembangan teknologi telekomunikasi dan informatika menjadi semakin terpadu (konvergensi media). Telepon seluler, dengan aneka fitur yang tersedia, berkembang menjadi bagian teknologi komunikasi dan informasi baru dan merupakan bagian dari media konvergensi. Akibatnya, lahir mekanisme baru dalam berkomunikasi yang ditandai dengan penggunaan multimedia, dimana teks, suara, gambar atau grafis dapat diakses sekaligus ke dalam satu media. Hal ini berdampak pada perkembangan ilmu komunikasi dan kajian gender dalam komunikasi. Beberapa penelitian melaporkan, ada perbedaan penggunaan teknologi di kalangan masyarakat. Laki-laki telah mendominasi teknologi, sedangkan perempuan telah dikeluarkan dari hubungannya dengan teknologi. Namun, dalam era globalisasi dan informasi sekarang ini tidak ada diskriminasi gender dalam penggunaan teknologi terutama teknologi seluler.
\end{abstract}

Kata kunci: Telekomunikasi, komunikasi, motif, kepuasan, fitur 


\section{PENDAHULUAN}

Ada Era globalisasi yang ditandai oleh perkembangan dan kemajuan di bidang teknologi komunikasi dan informasi telah membawa perubahan dalam berbagai aspek kehidupan manusia saat ini. Teknologi komunikasi dan informasi sekarang telah menjadi kebutuhan kedua bagi manusia, terutama di kota-kota besar. Banyak orang merasa kebingungan, jika telepon selulernya mengalami gangguan. Komputer hang dapat menimbulkan stress bagi pekerja dan mahasiswa. Akses internet lambat membuat sebagian remaja dan orang dewasa pengguna situs jejaring sosial tidak sabar. Beberapa contoh kasus di atas, menjadi bukti bahwa akhir-akhir ini teknologi informasi dan komunikasi telah menjadi perhatian masyarakat secara luas. Sebagaimana diungkapkan Vivian (2007:197):

Saat ini kita melewati fase transformasi dimana teknologi komunikasi sedang menentukan nasib dunia baru. Modal dan tenaga kerja lama secara berangsur digantikan oleh teknologi inovatif yang meliputi: robotika, komunikasi seluler, miniatur motor, komputer super, produksi perangkat lunak dan benda-benda lain yang memiliki kemampuan kerja tinggi. Kemajuan dan perkembangan teknologi internet dan komunikasi yang dimediasi oleh komputer (CMC) memperlihatkan bahwa revolusi teknologi komunikasi relatif masih baru. Aspek penting dari revolusi ini meliputi kecepatan, integritas, kecanggihan dan biaya. Menariknya, tingginya biaya telekomunikasi saat ini telah berkurang secara drastis dibandingkan dengan apa yang terjadi dalam dekade lampau.

Ledakan teknologi telah memperkenalkan sisi lain media dalam budaya masyarakat. Teknologi komunikasi telah menyeting standar dan parameter untuk mengukur kemajuan suatu masyarakat. Masyarakat saat ini dapat dibedakan pada dua kategori: orang yang memiliki akses terhadap teknologi modern dan mau memanfaatkannya dan orang yang tidak memiliki akses terhadap teknologi dan tidak mampu memanfaatkannya. Kedua kategori ini menunjukkan adanya perbedaan kelas social dengan identitas budaya yang berbeda.

Perkembangan teknologi digital memicu perkembangan teknologi telekomunikasi dan informatika menjadi semakin terpadu atau popular dengan istilah "konvergensi". Penggunaan sistim komputer dan sistim komunikasi ternyata juga menghadirkan media komunikasi baru. Yakni lahirnya mekanisme baru dalam berkomunikasi yang ditandai dengan penggunaan multimedia, dimana teks, suara, gambar atau grafis dapat diakses sekaligus ke dalam satu media. Bahkan, media baru telah menciptakan garis batas antara media tradisional dengan media komunikasi Modern. Sebagaimana digambarkan Mc Millan (2004) "kemajuan yang dihasilkan oleh teknologi informasi 
memungkinkan sebuah media memfasilitasi komunikasi interpersonal yang termediasi. ${ }^{1}$

Konvergensi media, memperkaya informasi yang disajikan dan memberi pilihan bagi khalayak untuk memilih informasi yang sesuai dengan selera mereka. Konvergensi media juga memberikan kesempatan baru secara radikal dalam penanganan, penyediaan, distribusi dan pemrosesan seluruh bentuk informasi, baik yang bersifat visual, audio, data dan sebagainya. Namun, Konvergensi media memunculkan berbagai konsekuensi penting yang menjadi tantangan berbagai pihak untuk mengantisipasinya. Tantangan konvergensi bisa untuk pemerintah, industri penyedia layanan konten, masyarakat pengguna jasa, hingga ke masyarakat umum yang mungkin secara tidak langsung bersentuhan dengan konvergensi media, tetapi bisa terkena efeknya. Pada gilirannya, konvergensi media akan menerpa media tradisional. Oleh karena itu, penting sejak awal menyiapkan pendidikan konvergensi media kepada khalayak.

Telepon seluler atau sering disebut handphone, adalah perangkat telekomunikasi elektronik yang mempunyai kemampuan dasar yang sama dengan telepon konvensional, namun dapat dibawa kemana-mana dan tidak perlu disambung dengan menggunakan kabel. Selain berfungsi untuk melakukan dan menerima panggilan, telepon seluler juga mempunyai fungsi pengiriman dan penerimaan pesan singkat (short message service). Mengikuti perkembangan teknologi digital, kini telepon seluler juga dilengkapi dengan berbagai pilihan fitur seperti: bisa menangkap siaran radio, televisi, perangkat lunak pemutar audio (mp3) dan video, kamera, game dan layanan internet.

Telepon seluler, dengan aneka fitur yang tersedia, berkembang menjadi bagian teknologi komunikasi dan informasi baru dan merupakan bagian dari media konvergensi. Konvergensi media menurut Henry Jenkins ${ }^{2}$, dalam Ramdani (2008) adalah aliran konten (informasi, gambar, audio, video dan lain-lain) ke pelbagai platform media, kerjasama antara pelbagai industri media serta prilaku audien yang memakai pelbagai media untuk mengkonsumsi konten. Konvergensi media bukan saja didesain secara top-down oleh perusahaan-perusahaan yang ingin memperluas jangkauan bisnis melalui pelbagai platform media, melainkan juga desain secara bottom-up oleh hasrat konsumen yang ingin menggunakan media dimanapun, kapanpun dan dalam format apapun yang mereka inginkan. fungsinya

2 Benny Ramdani, Konvergensi Media: Edukasi dan Regulasi, observasi. Vol.6, no.2. tahun 2008. 
jelas sudah tak sekedar alat komunikasi antarpersona.

Media komunikasi adalah institusi teknologi dan beberapa kalangan mengklaim bahwa laki-laki telah mendominasi teknologi, sedangkan perempuan telah dikeluarkan dari hubungan manusia dengan teknologi. Namun, mayoritas mempercayai bahwa tidak ada diskriminasi gender dalam penggunaan teknologi terutama teknologi seluler. Karena, teknologi seluler adalah koleksi dari teknologi digital terbaru. Telepon seluler adalah sebuah perangkat ekspresif yang memungkinkan kita untuk mengekspresikan perilaku sosial yang kompleks dan berbagai pola komunikasi individu. Meskipun demikian, beberapa hasil penelitian telah melaporkan bahwa ada perbedaan dalam penggunaan teknologi di kalangan masyarakat.

Berkaitan dengan komunikasi, perempuan dan laki-laki memiliki perbedaan, baik dalam penggunaan bahasa, gaya komunikasi, tujuan komunikasi maupun dalam penggunaan dan pemanfatan media komunikasi. Perempuan mengalami diskriminasi dan streotype dalam berbagai hal termasuk dalam pemanfaatan teknologi. Jika menoleh kepada sejarah, teknologi diaggap menjadi salah satu penyebab perempuan masuk dalam wilayah domestik, dimarginalkan dan dimiskinkan. Karena teknologi diciptakan oleh laki-laki dan untuk kepentingan laki-laki, sehingga teknologi menjadi dominasi laki-laki. Namun, dalam era keterbukaan dan era informasi, sebagaimana digambarkan MC Luhan bahwa dalam "global Village" orang dapat berkomunikasi secara individual satu sama lain hanya dimediasi oleh komputer, dan jaringan tanpa kabel (wireless), tidak ada editor dan tidak ada sensor, sebagaimana pada media massa. Implikasi sosial dari penemuan CMC (computer mediated communication), ini mempercepat perpindahan arus informasi dan pengetahuan sehingga mempermudah hidup manusia. Tidak ada hambatan gender, ras atau penampilan fisik, semua orang dapat berkomunikasi satu sama lain dengan mengurangi prasangka dan kesalahpahaman komunikasi. Karena itu, meneliti Perbedaan Gender dalam Penggunaan Telepon Seluler dan Motif Komunikasi Interpersonal di kalangan Siswa-siswi Madrasah Aliyah penting dilakukan..

\section{KERANGKA TEORI}

\section{Uses And Gratification Theory}

Penelitian tentang perbedaan gender dalam penggunaan telepon seluler dan Motif Komunikasi interpesonal di kalangan siswa akan dikaji menggunakan teori Uses and Gratification dari Katz dan Blumer .

Berdasarkan Katz et al (1973); Amri jahi (1988) model uses and gratification:1).orang yang berbeda dapat 
menggunakan pesan komunikasi yang sama untuk berbagai kebutuhan yang berbeda; 2) Isi media yang sama dapat memuaskan kebutuhan berbeda untuk individu yang berbeda; 3) ada berbagai alasan orang dalam menggunakan media.

Dalam konteks motif interpersonal, seseorang dapat memuaskan kebutuhan inklusinya dengan mengirim SMS, tetapi untuk orang lain mungkin menggunakan SMS untuk memuaskan rasa senang, dan bahagia. Hal yang sama juga terjadi pada Voice Call (panggilan suara). Seseorang mungkin untuk mengisi waktu luang atau sebagai pelarian dari kesibukan sehar-hari, ia akan melakukan panggilan suara, namun untuk orang yang lain, suasana rileks dirasakan justru saat yang tepat untuk melakukan panggilan suara. Bahkan voice call dan pesan tertulis mungkin dapat memuaskan lebih dari sau kebutuhan interpersonal pengirimnya.

\section{Teori Komunikasi Gender}

Perbedaan gender berpengaruh terhadap perbedaan prilaku komunikasi pada laki-laki dan perempuan. Dalam teori gender, secara umum laki-laki berbeda dari perempuan. Perbedaan tersebut terutama dalam aspek ekpresif, respektif dan instrumental (Parson \& Bales 1955).

Perbedaan gender merupakan hambatan terbesar dalam efektifitas komunikasi. Perbedaan gender dalam komunikasi mucul sejak masa anak-anak.
Karena sejak usia-usia awal anak laki-laki dan anak perempuan telah diajarkan gaya berbahasa dan berkomunikasi secara berbeda. Perilaku komunikasi anak perempuan tidak cocok untuk diterapkan pada anak laki-laki. Perempuan berkomunikasi menggunakan cara-cara khusus yang telah ditetapkan oleh masyarakat untuk mereka. seperti: berbicara pelan, sopan, tidak membuat keributan dan tampil menjadi sosok gadis yang manis dan anggun. Sementara, lakilaki harus berbicara keras, boleh berbicara kasar dan membuat keributan. Perempuan diajarkan untuk selalu menunjukkan perasaan, meminta dilindungi, dimanja dan bergantung pada orang lain, sebaliknya laki-laki diajarkan untuk selalu menunjukkan sikap kuat, tegar, tidak cengeng, dominan dan independen.

Persepsi mengenai teknologi merupakan masalah analisis gender dan ketika mengamati kebiasaan komunikasi diantara laki-laki dan perempuan, maka perlu menyadari berbagai cara dimana lakilaki dan perempuan memandang telepon secara umum. Laki-laki seringkali distereotipkan memiliki kompetensi lebih baik dalam hal teknologi, mengetahui, memiliki keterampilan dan kepentingan terhadap teknologi dibandingkan perempuan. Komunikasi menggunakan telepon seluler (mobile phone) menawarkan banyak keuntungan, tetapi juga memiliki 
sisi negatif. Misalnya, beberapa orang pengguna telepon seluler sudah merasa kecanduan. Rasa kecanduan ini berhubungan dengan besarnya ketergantungan mereka pada alat tersebut atau bisa dikategorikan sebagai pengguna berat (Katz, 2005). Pada sisi lain, penggunaan teknologi telepon seluler ini dapat meningkatkan minat siswa dalam kegiatan tertentu, misalnya untuk $e$ learning, tetapi perangkat yang terutama digunakan untuk komunikasi biasanya adalah berupa panggilan suara (voice call)) dan pesan teks/ pesan tertulis (Trifonofa et. al, 2006).

\section{METODE PENELITIAN}

\section{Tipe Penelitian}

Tipe penelitian ini adalah kuantitatif dengan menggunakan metode survei, yaitu cara pengambilan sampel sebagai data primer dari lapangan dengan menggunakan kuesioner dengan bentuk pertanyaan tertutup (Close-ended).

\section{Populasi dan Sampel.}

Populasi dalam penelitian ini adalah seluruh siswa Madrasah Aliyah Negeri (MAN) Model Babakan Ciwaringin Cirebon berjumlah 1693 orang dari 42 kelas. Sampel dalam penelitian ini sebanyak 100 orang. Tehnik pengambilan sampel didasarkan pada tehnik cluster Sampling. Tehnik pengambilan sampel dilakukan melalui beberapa tahap, dengan tehnik Simple Random sampling.

\section{Tehnik Analisis Data}

Analisis data dalam penelitian ini menggunakan analisis statistik deskriptif. Analisis deskriptif dilakukan untuk melihat frekuensi penggunaan telepon, jumlah penggunaan panggilan telepon dan penggunaaan pesan tertulis (SMS) dalam satu hari serta melihat motif penggunaan telepon diantara kedua jenis kelamin lakilaki dan perempuan. Analisis korelsional Pearson digunakan untuk melihat tingkat hubungan diantara motif-motif dalam penggunaan panggilan telepon (voice call) dan pesan tertulis (SMS).

\section{Definisi dan Operasioalisasi Variabel}

Variabel dalam penelitian ini terdiri dari dua Variabel yaitu: Variabel bebas (variabel X) adalah: penggunaan telepon. Variabel $\mathrm{X}$ terdiri dari: kebiasaan responden menggunakan telepon, frekuensi respoden menggunakan telepon dan jumlah (lamanya responden menggunakan telepon. Variabel terikat (variabel Y) adalah: Motif Menggunakan telepon meliputi 6 motif: Kesenangan, Afeksi, Inklusi, Eskapis, Relaksasi dan Kontrol.

\section{Instrumen Penelitian}

Instrumen yang digunakan dalam penelitian ini adalah kuesioner berupa pernyataan-pernyataan dan pertanyaan yang diajukan kepada responden untuk diberikan respon (jawaban). Bentuk 
pernyataan dan pertanyaan terdiri dari: 2 item pertanyaan tentang identitas responden yakni: jenis kelamin dan tempat tinggal; 15 item pertanyaan tentang kebiasaan dan frekuensi responden menggunakan telepon Seluler. Sedangkan untuk pertanyaan motif menggunakan telepon terdiri dari 16 item, meliputi: 8 item untuk motif menggunakan voice call dan 8 item untuk motif menggunakan SMS, dengan 5 option jawaban: Sangat Setuju (SS), Setuju (S), Netral (N), Tidak Setuju (TS) dan Sangat Tidak Setuju (STS).

\section{HASIL DAN PEMBAHASAN}

\section{Karakteristik Responden}

Responden dalam penelitian ini terdiri dari laki-laki dan Perempuan. Sampel responden direpresentasikan secara sama: laki-laki $50 \%$ dan perempuan $50 \%$. Distribusi Usia responden tidak diperlihatkan dalam penelitian ini karena penelitian ini lebih menekankan pada representasi gender. Sedangan tempat tinggal responden $67 \%$ tinggal di Pondok, $30 \%$ tinggal di Rumah dan hanya $3 \%$ tinggal di kost-an.

Perbedaan Gender dalam Penggunaan Telepon.

\section{Kebiasaan Responden Menggunakaan}

\section{Telepon Seluler}

Penelitian ini hanya memfokuskan pada dua channel dalam penggunaan telepon seluler yaitu: Voice Call (panggilan suara) dan Text Messaging (SMS). Hasil penelitian memperlihtkan bahwa dikalangan siswa, masih lebih banyak menggunakan SMS ( $91 \%$ ) dibandingkan dengan Voice Call (9 \% ). Namun, bila dilihat perbandingan antara laki-laki dan perempuan terdapat perbedaan, dimana laki-laki hanya $6 \%$ menggunakan Voice Call dan $94 \%$ menggunakan SMS, sedangkan perempuan $12 \%$ menggunakan Voice Call dan $88 \%$ menggunakan SMS.

Tempat yang paling sering digunakan responden untuk menggunakan telepon seluler adalah di rumah (58) \%, di sekolah $28 \%$ dan di Pondok (12\%), sisanya $2 \%$ menggunakan di tempat lain. Artinya, rumah merupakan tempat yang paling sering digunakan siswa untuk menelepon seluler (karena lebih bebas). Sementara pondok dan sekolah masih membatasi penggunaan telepon seluler terutama pada jam-jam belajar. Dengan demikian, dapat disimpulkan bahwa frekuensi penggunaan telepon ditentukan oleh lokasi saat menggunakan telepon.

Ada beberapa tujuan orang berkomunikasi menggunakan telepon seluler antara lain:1) Berhubungan dengan orang lain, 2) mencari informasi dan 3) sebagai gaya hidup. Hasil penelitian memperlihatkan $78 \%$ siswa menggunakan telepon Seluler untuk komunikasi (berhubungan dengan orang lain), $20 \%$ untuk mencari informasi dan $2 \%$ sebagai 
gaya hidup. Artinya, dikalangan siswa fungsi telepon seluler sebagai media komunikasi dan informasi, belum sampai pada taraf menjadi gaya hidup atau untuk menunjukan status sosial atau pamer kekayaan. Bila dilihat perbandingan antara laki-laki dan perempuan dalam tujuan komunikasi menggunakan telepon seluler, dapat ditunjukkan bahwa laki-laki $74 \%$ menggunakan telepon untuk tujuan komunikasi, $24 \%$ untuk informasi dan 2 $\%$ sebagai gaya hidup. Sedangkan Perempuan $82 \%$ untuk komunikasi, $16 \%$ untuk mencari informasi dan $2 \%$ sebagai gaya hidup.

Dari data di atas, dapat dijelaskan, secara umum orang masih memanfaatkan telepon seluler sebatas media komunikasi, dan informasi masih sangat rendah. Artinya, tidak ada perbedaan signifikan diantara laki-laki dan perempuan dalam tujuan menggunakan telepon seluler untuk komunikasi, yaitu $74 \%$ (laki-laki) dan 82 $\%$ (perempuan). Namun, dalam memanfaatkan telepon untuk tujuan mencari informasi, terlihat laki-laki lebih tinggi yaitu ( $24 \%$ ) dibandingkan perempuan (16\%). Hal ini dapat dipahami, bahwa secara teoritis ada perbedaan dalam tujuan komunikasi diantara laki-laki dan perempuan. Perbedaan ini juga berlaku untuk penggunaan telepon. Laki-laki berkomunikasi berorientasi pada tugas, maka penggunaan telepon bagi laki-laki bertujuan untuk pencarian informasi dalam kaitan dengan penyelesaian tugas-tugas sekolah dan membuat perencanaan. Sementara perempuan berkomunikasi berorientasi pada menjalin hubungan. Oleh karena itu, bagi perempuan menggunakan telepon untuk tujuan sosialisasi.

Perbedaan laki-laki dan perempuan dalam penggunaan telepon ini juga dapat terlihat dalam perilaku masing-masing. Misalnya, perempuan sering menggunakan telepon berjam-jam hanya untuk menyampaikan masalah pribadi, curhat atau gosip. Sedangkan Laki-laki menggunakan telepon untuk menyampaikan hal-hal yang prinsip misalnya: berbicara masalah politik, ekonomi, tugas dan olah raga.

\section{Frekuens Responden Menggunakan}

\section{Telepon Seluler}

Untuk melihat frekuensi responden menggunakan dan menerima telepon seluler, baik untuk voice call maupun SMS, penulis menawarkan 3 option jawaban untuk responden yaitu: a).1-5 kali sehari; b) 6-10 kali sehari dan c) lebih dari 10 kali sehari. Sampel digambarkan dalam tiga kategori; standar (pengguna biasa), sedang, dan tinggi (pengguna berat). Hasil penelitian memperlihatkan bahwa baik pada laki-laki maupun perempuan, menggunakan telepon untuk panggilan suara (voice call) sebagian besar pada tingkat intensitas yang standar (1-5) kali 
sehari, yakni sebesar $78 \%$. Sedangkan jika dibandingkan, maka perempuan lebih banyak menggunakan panggilan suara (voice call) yakni $82 \%$ dibandingkan lakilaki hanya $74 \%$.

Untuk menjawab pertanyaan tentang berapa kali dalam sehari responden menerima panggilan suara (voice call). hasilnya menunjukkan bahwa sebanyak 87 $\%$ responden menerima panggilan suara dalam sehari antara 1-5 kali, Artinya, masih dalam kategori standar. Sebanyak $7 \%$ berada pada kategori sering (>10) kali dan $5 \%$ berada dalam kategori sedang. Apabila dilihat perbandingan antara laki-laki dan perempuan ternyata perempuan lebih sering menerima panggilan suara daripada lakilaki.

Untuk intensitas penggunaan SMS hasil penelitian menunjukan bahwa baik pada laki-laki maupun pada perempuan, penggunaan telepon untuk SMS, sebagian besar pada tingkat intensitas yang standar (1-5) kali sehari, yakni $87 \%$. Sedangkan jika dibandingkan, maka laki-laki lebih banyak dibandingkan dengan perempuan yakni $88 \%$ dibandingkan perempuan hanya $87 \%$. Pada tingkat intensitas Sedang yakni (6-10 ) perempuan lebih tinggi yakni $8 \%$, dibandingkan laki-laki hanya $2 \%$ dan pada tingkat intensitas tinggi yakni (> 10), laki-laki terlihat lebih tinggi yakni $10 \%$ dibandingkan perempuan yakni $4 \%$.
Jadi, dapat disimpulkan bahwa tidak ada perbedaan signifikan dalam penggunaan telepon seluler diantara pengguna laki-laki dan perempuan. Hampir persentasenya sama (laki-laki $88 \%$ dan perempuan $87 \%$ ) dari populasi pengguna telepon seluler. Dengan demikian, hasil penelitian tidak menunjukkan perbedaan penggunaan telepon seluler pada kedua kelompok gender. Secara keseluruhan dapat disimpulkan, laki-laki lebih banyak menggunakan SMS dibandingkan perempuan baik untuk kategori pengguna biasa maupun untuk pengguna berat (sering), sementara perempuan lebih banyak menggunakan panggilan suara, sekalipun masih berada pada kategori standar.

Berkaitan dengan frekuensi menerima SMS, hasil penelitian memperlihatkan bahwa sebanyak $56 \%$ responden sering menerima SMS dalam 1 hari lebih dari 10 kali, sisanya berada dalam kategori biasa dan sedang masingmasing sebanyak $22 \%$. Namun, jika dilihat perbandingan antara laki-laki dan perempuan dalam frekuensi menerima SMS, hasil penelitian diperoleh bahwa pada kategori tinggi perempuan lebih tinggi 56 $\%$ daripada laki-laki $44 \%$, pada kategori standar laki-laki lebih tinggi $59 \%$ dan perempuan $41 \%$, pada kategri sedang juga laki-laki lebih tinggi $56 \%$ dan perempuan $46 \%$. Artinya, laki-laki lebih sering 
membuat SMS daripada meerima SMS, sementara perempuan lebih sering menerima SMS dibandingkan laki-laki.

Lamanya responden melakukan panggilan suara (voice call) dalam sehari dapat diketahui dari tabel di bawah. Sebagian besar responden (57 \%) menyatakan dalam satu hari rata-rata melakukan panggilan suara sebanyak 1-10 menit, artinya masih dalam kategori standar, sedangkan $24 \%$ melakukan panggilan suara lebih dari 20 menit atau berada dalam kategori sering dan hanya 19 $\%$ responden melakukan panggilan sekitar 11-20 menit termasuk dalam kategori sedang. Data di atas, dapat dijelaskan bahwa lamanya responden menggunakan telepon masih dalam kategori wajar, hal ini mungkin berkaitan dengan biaya (cost) yang harus dikelurakan, dimana siswa madrasah secara ekonomi masih bergantung kepada orang tua dan kebanyakan orang tua di Indonesia belum menganggap penting anggaran untuk komunikasi.

Sedangkan lamanya responden menerima panggilan suara, hasil penelitian menunjukkan bahwa $57 \%$ menerima panggilan suara selama 1-10 menit (kategori standar), $24 \%$ menerima panggilan 11-20 menit (kategori sedang) dan sebanyak $19 \%$ menerima panggilan selama > 20 menit. Dari dua tabel di atas, dapat disimpulkan bahwa baik laki-laki maupun perempuan melakukan dan menerima panggilan suara sama-sama ada pada kategori standar yaitu selama 1-10 menit. Sedangkan terdapat variasi pada kategori sedang dan sering, $24 \%$ responden melakukan panggilan suara selama > 20 menit (kategori Tinggi) dan 19 $\%$ responden melakukan selama 11-20 menit ( kategori sedang). Namun, dalam menerima panggilan suara justru berbanding terbalik. Artinya, $24 \%$ menerima panggilan suara selama 11-20 menit (kategori sedang) dan $19 \%$ menerima panggilan suara selama lebih dari 20 menit (kategori tinggi). Hal ini dapat dipahami bahwa rata-rata orang senang melakukan panggilan suara (menelepon) secara berjam-jam (lama)) dibandingkan dengan menerima (mendengarkan) telepon selama berjamjam.

Sebagian besar responden mengirim SMS menghabiskan waktu selama 1-10 menit (kategori standar) yaitu sekitar $90 \%$, sebanyak $6 \%$ mengirim SMS selama $>20$ menit dan hanya $4 \%$ mengirim SMS selama 11-20 menit. Sedangkan untuk lamanya menerima SMS diketahui $\begin{array}{lllll}\text { sebanyak } & 79 \quad \% & \text { menerima SMS }\end{array}$ menghabiskan waktu antara 1-10 menit, 13 $\%$ menghabiskan waktu 11-20 menit dan 8 $\%$ menghabiskan waktu selama $>20$ menit. Kesimpulannya, pemanfaatan SMS baik 
untuk mengirim maupun menerima masih dalam batas-batas standar.

Untuk menjawab pertanyaan kepada siapa anda paling sering mengirim voice call, hasil penelitian memperlihtkan $68 \%$ untuk menelepon keluarga, $31 \%$ menelepon teman dan $1 \%$ menelepon guru. Sedangkan, pertanyaan tentang dari siapa paling banyak menerima telepon, hasil penelitian menyatakan bahwa $72 \%$ dari keluarga dan sisanya $28 \%$ menerima dari teman.

Apabila dilihat perbandingan antara laki-laki dan perempuan dapat dijelaskan bahwa $60 \%$ laki-laki sering menerima panggilan suara (voice call) dari teman, perempuan hanya $40 \%$, sedangkan untuk terima panggilan dari keluarga perempuan lebih tinggi $55 \%$ daripada laki-laki $45 \%$. Artinya, dapat disimpulkan bahwa lakilaki lebih sering menerima panggilan suara dari teman-teman dibandingkan dari keluarga, sementara perempuan lebih sering menerima panggilan suara dari keluarga. Hal ini dapat dipahami karena perempuan lebih aktif melakukan panggilan suara kepada keluarga dibandingkan laki-laki, maka perempuan lebih sering menerima panggilan suara dari keluarga dibandingkan laki-laki. Selain itu, temuan ini juga berkaitan dengan sikap dan perlakuan keluarga yang berbeda terhadap laki-laki dan perempuan, dimana laki-laki diberi kebebasan dalam aktifitas di wilayah publik tanpa dikontrol secara berlebihan, sedangkan perempuan lebih banyak diawasi dalam aktifitas di wilayah publik. Lihat Tabel di bawah:

Untuk pertanyaan kepada siapa responden paling sering mengirim SMS, hasil penelitian menunjukkan bahwa $81 \%$ sering mengirim SMS kepada teman, $19 \%$ kepada keluarga, $2 \%$ kepada guru dan $2 \%$ kepada lainnya ( pacar ). Sedangkan untuk pertanyaan tentang dari siapa paling banyak menerima SMS, Jawaban yang diperoleh dari penelitian menyatakan $84 \%$ sering menerima SMS dari teman dan $19 \%$ dari keluarga.

Kesimpulannya, pemanfaatan SMS dikalangan siswa masih lebih besar untuk berkomunikasi dengan teman, selebihnya berkirim dan bertukar pesan dengan keluarga. Namun, hanya sedikit (relatif kecil) fungsinya untuk berkomunikasi lewat pesan tertulis dengan guru.

Namun, jika melihat perbandingan antara laki-laki dan perempuan kepada siapa meeka palig sering mengirim dan menerima SMS dapat dijelaskan bahwa Laki-laki lebih sering mengirim SMS kepada kepada keluarga $53 \%$, perempuan $47 \%$, sementara untuk mengirim SMS kepada temanperempuan lebih tinggi $51 \%$ dibandingkan Laki-laki 49 5. Namun untuk terima SMS laki-laki lebih sering menerima SMS dari teman $51 \%$ dan 
perempuan $49 \%$, sedangkan untuk terima SMS dari keluarga dan guru tidak ada perbedaan antara kedua jenis kelamin tersebut.

\section{Perbedaan Gender dalam Motif} Menggunakan Telepon Seluler.

Untuk mengetahui apakah ada perbedaan antara laki-laki dan perempuan dalam motif interpersonal menggunakan Voice Call untuk memenuhi kebutuhan mencari kesenangan (hiburan), hasil penelitian ditunjukkan dalam tabel di bawah, dalam kategori rendah laki-laki cenderung lebih tinggi yaitu $100 \%$, sementara pada kategori sedang perempuan lebih tinggi yaitu $53 \%$ dan pada kategori tinggi laki-laki lebih tinggi $52 \%$ daripada perempuan $48 \%$. Artinya, laki-laki menggunakan voice call untuk alasan memenuhi kepuasan kesenangan atau hiburan, sementara perempuan motif menggunakan voice call untuk hiburan lebih rendah.

Seseorang sering menggunakan telepon seluler dalam bentuk voice call dengan motif untuk memenuhi kebutuhan afeksi (mengungkapkan perasaan) terhadap orang lain, misalnya terhadap orang-orang tercinta. Untuk mengetahui perbedaan motif menggunakan voice call untuk afeksi antara laki-laki dan perempuan hasil tabulasi silang memperlihatkan bahwa pada kategori rendah dan sedang perempuan (75 $\%$ dan $59 \%$ ) lebih tinggi daripada laki-laki
(25\% dan $40 \%$ ), namun pada kategori tinggi ternyata laki-laki lebih tinggi $65 \%$ dan perempuan $34 \%$. Artinya, laki-laki sebagain besar menggunakan Voice Call untuk memenuhi kebutuhan afeksi.

Perbedaan laki-laki dan perempuan dalam motif menggunakan voice call untuk tujuan Escapes (pelarian atau mengisi waktu luang) ditunjukkan dalam tabel dibawah bahwa pada kategori rendah tidak ada perbedaan antara laki-laki dan perempuan, sedangkan pada kategori sedang laki-laki lebih tinggi $51 \%$ dan perempuan $48 \%$, sementara pada kategori tinggi perempuan lebih tinggi $54 \%$ dibandingkan laki-laki $45 \%$ Artinya, disini dapat disimpulkan bahwa motif Escapes (mengisi waktu luang) pada perempuan dapat dipuaskan dengan melakukan panggilan suara (voice call). Hal ini dapat diperkuat dengan data tentang frekuensi penggunaan telepon di atas, bahwa perempuan lebih banyak menggunakan voice call dibandingkan dengan laki-laki. Secara teoritis dapat dijelaskan bahwa perempuan lebih banyak menggunakan komunikasi verbal dibandingkan laki-laki.

Motif inklusi adalah motif untuk diakui menjadi bagian dari orang lain atau untuk memiliki perasaan sama dengan orang lain. Kebutuhan untuk diakui, atau dianggap sebagai bagian dari orang lain / kelompok merupakan kebutuhan setiap 
manusia. Artinya, seringkali orang berkomunikasi dengan orang lain, tidak melulu karena kebutuhan mencari informasi atau menjalin hubungan, tetapi juga untuk memenuhi kepuasan diri merasa sama atau diakui orang lain. Kebutuhan untuk inklusi ini pada sebagian orang dapat dipuaskan melalui komunikasi dengan menggunakan telepon. Laki-laki dan perempuan sama-sama memiliki kebutuhan interpersonal inklusi. Apakah laki-laki dan perempuan memiliki perbedaan dalam motif menggunakan voice call untuk memenuhi kepuasan inklusi?, hasil penelitian memperlihatkan bahwa pada kategori rendah perempuan lebih tinggi 63 $\%$ dari pada laki-laki $36 \%$, namun pada kategori sedang dan tinggi laki-laki lebih tinggi daripada perempuan untuk motif inklusi, masing-masing $52 \%$ dan $66 \%$. Temuan di atas, dapat disimpulkan bahwa laki-laki cenderung lebih terpuaskan kebutuhan inklusinya melalui kegiatan membuat panggilan suara ( voice call) dibandingkan perempuan.

Dari hasil tabulasi silang antara jenis kelamin dengan motif menggunkan voice call untuk relaksasi terlihat bahwa untuk kategori rendah laki-laki lebih tinggi $66 \%$ daripada perempuan $34 \%$, sedangkan pada kategori sedang dan tinggi, perempuan sedikit lebih tinggi $(50 \% ; 50 \%)$ daripada laki-laki (49\%; $48 \%$ ). Artinya, dalam kategori sedang dan tinggi ditemukan hampir tidak ada perbedaan diantara lakilaki dan perempuan dalam motif menggunakan voice call untuk relaksasi, namun pada kategori rendah ditemukan laki-laki lebih tinggi $66 \%$. Artinya, Sebagian besar laki-laki tidak menggunakan Voice call untuk relaksasi.

Motif interpersonal kontrol yang dioperasionalkan sebagai motif untuk memperoleh pemenuhan atau kepatuhan dari teman-teman atau orang-orang disekitarnya, ketika mereka meminta untuk melakukan sesuatu atau motif untuk menunjukkan kuasa atas orang lain. Motif menggunakan voice call untuk menunjukkan power terhadap orang lain, ditemukan bahwa pada kategori tinggi dan sedang relatif tidak ada perbedaan antara laki-laki ( $50 \%$; $50 \%$ ) dan perempuan yaitu (50\%; $49 \%)$. Namun pada kategori rendah terlihat perempuan lebih tinggi (51 $\%$ ) daripada laki-laki $48 \%$. Artinya, motif menggunakan voice call untuk memenuhi kebutuhan kontrol atau memperoleh kepatuhan terlihat hampir sama pada kedua kelompok gender. Artinya, motif kontrol dalam penggunaan voice call tidak menjadi alasan utama menggunakan voice call. Meskipun secara teoritis, laki-laki lebih memiliki kecenderungan untuk memiliki motif kontrol dalam penggunaan voice call, Sebab laki-laki umumnya berkomunikasi untuk menetapkan status, kebebasan atas orang . 
Perempuan menggunakan SMS pada level pengguna standar (biasa), tetapi lakilaki mendominasi penggunaan SMS untuk kategori pengguna sedang dan Pengguna berat. Akibatnya, laki-laki lebih banyak menerima SMS daripada perempuan. Untuk motif menggunakan SMS untuk memperoleh kesenangan (hiburan), hasil penelitian menunjukan bahwa pada kategori rendah laki-laki mencapai $100 \%$, pada kategori sedang laki-laki lebih tinggi $50 \%$ dan perempuan $49 \%$, pada kategori tinggi perempuan lebih tinggi $65 \%$ dan laki-laki $35 \%$. Artinya, sekalipun laki-laki lebih banyak menggunakan SMS, namun penggunaan SMS untuk memenuhi kepuasan kesenangan relatif lebih sedikit pada lak-laki dibandingkan pada perempuan.

Motif menggunakan SMS untuk afeksi (menunjukkan perasaan kasih sayang terhadap orang lain terlihat bahwa $53 \%$ laki-laki lebih menyukai SMS untuk menunjukkan perasaan sayang (cinta) terhadap seseorang, $47 \%$ perempuan menggunakan SMS untuk menyatakan perasaan sayang kepada orang lain. Pada kategori rendah $57 \%$ dan kategori tinggi $52 \%$ laki-laki lebih tinggi dibandingan perempuan $42 \%$ dan $47 \%$. untuk menyatakan perasaan kasih sayang melalui SMS. Meskipun laki-laki lebih tinggi dalam menyatakan kasih sayang kepada teman atau keluarga melalui SMS, namun penyampaian afeksi melalui voice call lebih menjadi pilihan laki-laki, (lihat tabel di bawah).

Motif menggunakan SMS untuk memenuhi kebutuhan inklusi hasil penelitian menyatakan bahwa pada kategori tinggi $90 \%$ perempuan memilih menggunakan SMS untuk memuaskan motif interpersonal inklusi, dan hanya $10 \%$ pada laki-laki, Sedangkan pada kategori rendah laki-laki lebih tinggi mencapai $58 \%$ dari perempuan $42 \%$ untuk memilih membuat SMS dan pada kategori sedang laki -laki lebih tinggi $56 \%$ dibandingkan perempuan $43 \%$. . Dari data tersebut dapat disimpulkan bahwa motif inklusi lebih besar ditemukan pada perempuan. Hal ini dapat dipahami bahwa perempuan dalam berkomunikasi memiliki tujuan sosial, karena itu, kecenderungan untuk diakui, menjadi bagian dari kelompok, dan menjadi sama dengan orang lain menjadi alasan perempuan menggunakan SMS.

Motif orang menggunakan SMS atau berkirim pesan tertulis diantaranya untuk mengisi waktu luang atau sebagai pelarian dari kesibukan dan rutinitas sehari-hari. Berkaitan dengan perbedaan gender dalam motif interpersonal Escapis dijelaskan bahwa pada kategori tinggi laki-laki $51 \%$ dan $49 \%$ pada perempuan, pada kategori rendah ada perbedaan antara laki-laki $62 \%$ dan perempuan $32 \%$, namun pada kategori 
sedang perempuan lebih tinggi $57 \%$ dari perempuan $43 \%$. Dari data tersebut dapat disimpulkan bahwa laki-laki menggunakan SMS untuk memenuhi kebutuhan escapes (pelarian).

Untuk motif menggunakan SMS untuk kontrol, hasil penelitian menemukan bahwa $52 \%$ laki-laki pada kategori tinggi dan $48 \%$ perempuan, pada kategori rendah laki-laki lebih tinggi $54 \%$ dan perempuan $46 \%$, sedangkan pada kategori sedang $55 \%$ perempuan lebih tinggi dibanding laki-laki $45 \% \%$. Dari hasil tabulasi tersebut dapat disimpulkan bahwa laki-laki menggunakan SMS untuk berkomunikasi dalam rangka ingin menunjukkan kuasa, pengaruh, kepatuhan terhadap orang lain.

Penelitian ini menganalisis motif interpersonal untuk menggunakan telepon seluler dan perbedaan gender dalam motive dan penggunaan telepon seluler. Hasilnya menyatakan bahwa orang dapat memenuhi kebutuhan interpersonal secara memuaskan ketika menggunakan teks tertulis dibandingkan dengan voice call. Dalam penelitian ini pengguna telepon seluler dapat dibagi pada tiga kategori: pengguna biasa (standar), sedang dan pengguna berat. Sedangkan motif interpersonal untuk menggunakan voice call dan membuat SMS yang terutama muncul adalah relaksasi, inclusi dan afeksi.
Laki-laki lebih banyak menggunakan SMS, sementara perempuan lebih banyak menggunakan voice call. Penggunaan SMS bagi laki-laki berkaitan dengan motif untuk memperoleh kesenangan, menyampaikan perasaan sayang dan kontrol. Sedangkan Penggunaan voice call lebih banyak dilakukan perempuan dibandingkan lakilaki. Hal ini sesuai dengan karakteristik komunikasi perempuan yang berorientasi pada hubungan, kerjasama dan keakraban. Penggunaan voice call lebih memudahkan untuk menjalin hubungan, keakraban dibandingkan menggunakan SMS. Sedangkan Laki-laki karakteristik komunikasinya berorientasi pada tugas, sehingga penggunaan telepon seluler bagi laki-laki tidak sekedar alat komunikasi tetapi juga memiliki fungsi untuk mencari informasi.. Penggunaan telepon seluler diantara dua kelompok jenis kelamin terutama digunakan untuk SMS dan masih dalam batas standar (pengguna biasa)). Hasil penelitian secara keselurhan menjelaskan bahwa tidak ada perbedaan signifikan diantara laki-laki dan perempuan dalam penggunaa telepon seluler dalam frekuensi menggunakan panggilan suara dan SMS maupun dalam motif menggunakan telepon Artinya, prbedaan antara laki-laki dan perempuan dalam penggunaan telepon seluler untuk kedua jenis saluran voice call maupun SMS, 
hanya kecil sekali. Anggapan bahwa lakilaki lebih memiliki kompetensi dalam pengetahuan, keterampilan dan sikap terhadap teknologi hanya berdasarkan pada stereotipe masyarakat semata.

\section{PENUTUP}

Berdasarkan hasil penelitian yang telah penulis paparkan di atas, maka kesimpulan dari penelitan ini adalah:

1.Tidak ada perbedaan signifikan antara laki-laki dan perempuan dalam frekuensi penggunaan telepon seluler untuk jenis saluran Voice Call di kalangan siswa. Artinya, baik laki-laki maupun perempuan berada dalam kategori pengguna biasa. (casual user). Namun, ada perbedaan kecil antara laki-laki dan perempuan, dimana perempuan lebih banyak menggunakan Voice Call dibandingkan laki-laki. Hal ini sesuai dengan karakteristik komunikasi perempuan yang berorientasi pada hubungan, keakaraban dan kooperatif, maka perempuan menggunakan Voice Call untuk tujuan tersebut.

2. Tidak ada perbedaan signifikan antara laki-laki dan perempuan dalam frekuensi penggunaan telepon seluler untuk jenis saluran SMS (layanan pesan tertulis) di kalangan siswa. Artinya, baik laki-laki maupun perempuan berada dalam kategori pengguna SMS standar (casual user). Laki-laki lebih banyak menggunakan SMS dibandingkan perempuan. Hal ini sesuai dengan karakteristik komunikasi laki-laki yang berorientasi pada tugas, status dan dominasi terhadap orang lain, maka laki-laki menggunakan SMS untuk tujuan tersebut.

3. Tidak ada perbedaan signifikan dalam motif komunikasi interpersonal penggunaan telepon seluler untuk saluran voice call pada laki-laki dan perempuan untuk motif kesenangan, hal itu terjadi karena alasan cost (biaya yang harus dikeluarkan (misalnya mengeluarkan biaya untuk pulsa).

4. Tidak ada perbedaan signifikan dalam motif komunikasi interpersonal penggunaan telepon seluler untuk saluran SMS (Layanan Pesan Tertulis) pada laki-laki maupun perempuan untuk motif kesenangan. Artinya, sebagaian besar responden mereka memilih SMS untuk memenuhi kebutuhan mencari kesenangan. Meski demikian, terdapat perbedaan kecil diantara keduanya yaitu laki-laki lebih banyak menggunakan SMS untuk memenuhi kebutuhan kesenangan (kategori pengguna berat) dibandingkan perempuan.

5. Untuk motif inklusi, hasil penelitian menunjukkan bahwa baik laki-laki maupun perempuan memilih 
menggunakan voice call untuk menelepon teman. Namun, dalam konteks motif inklusi ini ternyata lakilaki lebih banyak menggunakan voice call untuk memenuhi kebutuhan inklusi dibandingkan perempuan. Sebaliknya, penggunaan SMS untuk memenuhi motif inklusi digunakan oleh laki-laki dan perempuan. Namun, jika dibandingkan antara keduanya, lakilaki lebih banyak menggunakan SMS untuk memenuhi motif inklusi dibandingkan perempuan.

6. Untuk motif relaksasi, sebagian besar responden tidak mnggunakan voice call untuk memenuhi kebutuhan relaksasi. Namun, jika dibandingkan segmen perempuan lebih banyak menggunakan voice call untuk relaksasi dibandingkan laki-laki.

7.Untuk motif relaksasi dengan menggunakan SMS, sebagain besar responden menggunakan SMS untuk tujuan ini. Namun demikian, perempuan lebih tinggi menggunakan SMS untuk tujuan relaksasi dibandingkan laki-laki.

8. Untuk motif kontrol untuk penggunaan voice call, hanya sebagian kecil menyatakan memilih menggunakan voice call untuk memenuhi kebutuhan kontrol (menunjukkan kuasa, atau dominansi terhadap orang lain). Namun, laki-laki lebih tinggi dari pada perempuan dalam menggunakan voice call untuk tujuan kontrol.

9. Untuk motif afeksi dalam penggunaan voice call dan SMS, sebagain besar perempuan lebih suka menggunakan SMS untuk menyatakan perasaan cinta dan perhatian kepada orang yang disayangi dibandingkan dengan lakilaki. Meskipun laki-laki lebih banyak menyampaikan perasaan kepada teman dan keluarga menggunakan SMS, namun menggunakan Voice call untuk menyatakan perasaan cinta dan perhatian terhadapap pacar lebih disukai laki-laki.

10. Untuk motif escapes, dalam penggunaan telepon baik untuk Voice call maupun SMS, sebagian besar responden tidak setuju menggunakan voice call untuk memenuhi kebutuhan escapes (pelarian atau mengisi waktu luang). Namun demikian, tidak ada perbedaan diantara laki-laki dan perempuan dalam penggunaan SMS maupun Voice Call untuk kebutuhan escapes.

\section{DAFTAR PUSTAKA}

Don Ihde, 2008. Filsafat Teknologi, Yogjakarta. Kanisius.

Tumenggung, D Adelin, 2005. Laba-laba Media: Hidup dalam Galaksi Informasi. Jakarta. Lembaga Studi Press dan Pembangunan. 
Deborah Tannen, 2003. You Just Don't Understanding, terj, Erick Ekoputra. Bandung: Qonita Mizan.

Dominic Srinati, 2004. Popular Culre, Pengantar Menuju Teori Budaya Populer, Yogjakarta: Bentang Pustaka.

Mulyana, Deddy, Solatun, 2007. Metodologi Penelitian Komunikasi. Bandung: PT Remaja Rosdakarya.

Katherin Miller, 2002. Communication Theories: Perspectives, Process and Contexts, USA: Mc Grall Hill Companies.

Linda Stillman, 2006. Culture, Communication and Gender: Moving The MDGs Forward, Global Watch: Summer, I, 1; ABI/INFORM Global.

Stephen W. Littlejohn, 1996. Theories Of Human Communication. California: Wadsworth Publishing Company

Rakhmat, Jalauddin. 1985. Metode Penelitian Komunikasi. Bandung. Remaja Rosdakarya.

Wood, J. T. (1997). Communication Theories in Action: An introduction. Belmont, CA: Wadsworth,

Idi Subandi Ibrahim. (ed.). 1998. Wanita dan Media: Konstruksi Idiologi Gender dalam Ruang Publik Orde Baru. Bandung : Rosdakarya.

John Fiske. Cultural And Communication Studies. Terj Yosi Iriantara \& Idi Subandi Ibrahim. Yogjakata : Jalasutra

Stephen Little John, 2009, Encyclopedia of Communication Theory. California: Sage Publication, Inc.

Burhan Bungin, 2009, Sosiologi Komunikasi. Jakarta: Prenada Media Group.
Nina Winangsih Syam, 2009. Sosiologi Komunikasi. Bandung: Humaniora.

Sue Thornham,2000. (Terj.). Feminist Theory and Cultural Studies. Yogjakarta: Jalasutra.

Jurnal Perempuan Untuk Pencerahan dan Kesetaraan, 2000. N0.14, Jakarta: Yayasan Jurnal Perempuan.

Rubin, RB. Perse, E.M. Barbato, C.A. 1988. Conceptualizing and measurement of Interpersonal Communication Motives, Human Communication Research, Vol.14, 602/628.

Rakow. L. 1988. Women and the Telephone: Gendering of Communications Technology. Dalam Kramarae, Technology and Women'S Voice, New York: Rutledge \& Kegan paul.

Vivian, John. 2007. The Media of Mass Communication. Boston. Pearson education Inc.

Wajcmen, J. 1991. Feminism Confronts Technology. Cambridge: Polity Press.

Iqbal, Jafar. 2010. Gender Differences in Mobile Phone. Eurojournal. Vol.46. N0.4. 